\title{
Stabilization of Marine Clay Soil Using Polyurethane
}

\author{
Samaila Saleh ${ }^{1 \& *}$, Nur Zurairahetty Mohd Yunus ${ }^{2},{\text { Kamarudin } \mathrm{Ahmad}^{3} \text { and Nazri Ali }}^{4}$ \\ ${ }^{1}$ Postgraduate Researcher, Faculty of Civil Engineering, Universiti Teknologi Malaysia, Johor Bahru, Malaysia \\ ${ }^{2}$ Senior Lecturer, Faculty of Civil Engineering, Universiti Teknologi Malaysia, Johor Bahru, Malaysia \\ $3 \& 4$ Associate Professor, Faculty of Civil Engineering, Universiti Teknologi Malaysia, Johor Bahru, Malaysia \\ *Corresponding author: samailasaleh@graduate.utm.my
}

\begin{abstract}
Many chemicals stabilisation techniques are being employed all over the world to improve the engineering and physical properties of the problematic soils and reduce the potential damages caused by them. Out of those chemical stabilisation technics, application of Polyurethane to improve the strength of marine clay was investigated in the laboratory. Characterization of the soil geotechnical properties was carried out by conducting laboratory test that includes natural moisture content, Atterberg limits, grains sizes analyses, specific gravity, moisture-density relationship, unconfined compressive strength (UCS), organic matter content and PH tests. Unconfined compressive strength test at optimum moisture content with varying the dose of the Polyurethane content was conducted to test the effectiveness of Polyurethane as a chemical stabiliser. The result of the preliminary tests of the sample shows that the soil has a liquid limit of $65 \%$, plastic limit of $26 \%$ and plasticity index of $53 \%$. The percentages of gravel, sand and fines in the marine clay sample were $0 \%, 1.32 \%$ and $98.68 \%$ respectively $\%$. The results of the UCS test also revealed that Polyurethane stabilisation improved the strength of marine clay by $230 \%$. Thus, the improvement in strength of stabilised marine clay soil can significantly reduce the overall thickness of the pavement and total cost of the road construction in future.
\end{abstract}

Keywords: Marine clay; Polyurethane; Strength improvement and Unconfined compressive strength

\section{Introduction}

The continuous increases in population called for infrastructural development in the coastal areas which has a lot of marine clay deposit. Although constructing these infrastructures needs a good foundation soil; however, marine clay is not suitable for that purpose. It is characterised by significant swelling and shrinkage when exposed to variations in moisture content. It also has the low bearing capacity and reduced permeability. Its natural moisture content is higher than its liquid limit. Its lateral swelling pressure is around 2-10 times larger than the vertical swelling pressure [1]. The unconfined compressive strength is between 25 to $50 \mathrm{kPa}$ [2]. These properties showed that marine clay is not suitable for use as a foundation material. Therefore, Geotechnical Engineers must provide solutions to this problem through soil stabilisation.

Stabilization of marine clay has received considerable attention in the relevant literature. Material like cement[3]-[8] and lime [9]-[12] were reported to have successfully stabilised marine clay. Although the improvement of strength is good enough, however, the price of these materials and the extended curing period they require makes it prohibitive. Other researchers treated the marine clay with waste material. Materials like rice husk ash, carbide slag [13], sawdust [10], locust bean waste ash [14]-[17], banana fibre [18], crumble rubber [19], ceramic waste [20], and ground granulated blast furnace slag [21]. However, these waste materials were only able to reduce the cost but unable to minimise the curing period. 
Therefore, another option is the applications of chemicals. Inorganic materials like Sodium silicate [13], [22][24]; and an organic chemical like N-Methylolacrylamide, Epoxy resin, Amino plast, Phenoplast, Lignosulfonate [25], [26]. However, the rheological properties, environmental impact. toxicity and local regulations limited the use of chemicals for soil stabilisation. Nevertheless, the promising properties of Polyurethane like high strength, low viscosity and density, short gelling time and inertness chemically after hardening are encouraging and lead to this research on investigation its application to stabilise marine clay.

Previous findings showed that polyurethane has been in use for civil engineering projects in many countries like USA, China, Italy, Korea, Malaysia, Iran and many more. Application of polyurethane grout in soil nailing decrease settlement of the ground from $5.33 \mathrm{~mm}$ to $2.002 \mathrm{~mm}$ and from $4.71 \mathrm{~mm}$ to $1.818 \mathrm{~mm}$ respectively [27]. Similarly, application of the polyurethane grout as micro piles modify the dynamic response of the ground [28], [29]. Injecting Polyurethane foam into the pavement subgrade improved the strength, stiffness and bearing resistance of the pavement [30]-[32]. Furthermore, [28] and [33] recommended Polyurethane grout for remedial action during Tunneling. However, there is no report of application polyurethane to stabilise marine clay. Therefore, this paper intend to report the laboratory investigation of the application of Polyurethane chemical for stabilisation of marine clay.

Polyurethane is a polymer material that is synthesis by the chemical reaction between the diisocyanate and a polyol to produce the urethane which is the repeating unit in Polyurethane[31], [34]-[36]. The properties of Polyurethane depend mainly on the type of Isocyanate, polyol and additives used in its synthesis process [37]. Polyurethane is now used globally as a construction material [35], [38], [39].

\section{Materials and specimen preparation}

The materials for this research are marine clay (soil) and rigid Polyurethane (stabiliser) shown in Error! Reference source not found.. A disturbed sample of marine clay was obtained from Batu Pahat in the campus of Universiti Tun Hussein Onn Malaysia (UTHM) Johor Bahru Malaysia. Backhoe excavator excavated the sample at a depth of $1.5 \mathrm{~m}$. NCL Chemical \& Equipment, Selangor Malaysia supplied the rigid Polyurethane. Table 1 shows the properties of the Polyurethane given by the manufacturer.

The collected marine clay sample was air dried for two weeks and then ground to smaller particles sizes as per [40] standard procedure for dry sample preparation. Then, the dried soil samples undergo a series of laboratory tests as per [41]-[43] standard procedure for the characterisation of the soils. The tests carried out for the characterisation of the marine clay are Atterberg limits tests, grain sizes analysis, moisture-density relationship, PH test, Lost of Ignition test and unconfined compressive strength (UCS) tests.

Performing unconfined compressive strength tests (UCS) on marine clay evaluated the effect of Polyurethane on marine clay properties. The marine clay mixed with optimum moisture content (OMC) and different dosage of polyurethane. The volume of Polyurethane that corresponding to $0 \%, 1 \%, 2 \%, 3 \% 4 \%$ and $5 \%$ of the bulk mass of the soil sample was added and mixed with the soil and compacted as quick as possible before the hardening of the Polyurethane and soil. The moulded and compacted soil was allowed to stay in the mould for some few minutes for the reaction of Polyurethane to complete before extruding from the mould and then tested with the UCS testing machine after 1-day curing. The $0 \%$ Polyurethane content samples were tested immediately after compaction. The tests were repeated twice in order to ensure the consistency of the results.

Table 1. Properties of polyurethane specified by the manufacturer

\begin{tabular}{|c|c|c|c|}
\hline \multirow[t]{2}{*}{ Properties } & \multirow[t]{2}{*}{ Unit } & \multicolumn{2}{|c|}{ Components of the Polyurethane } \\
\hline & & Polyol & Isocyanate \\
\hline Appearance & - & Amber liquid & Dark brown liquid \\
\hline Viscocity at $25^{\circ} \mathrm{c}$ & mPa.s & $260 \pm 50$ & $185 \pm 35$ \\
\hline Specific gravity at $25^{\circ} \mathrm{c}$ & - & $1.15 \pm 0.01$ & $1.24 \pm 0.01$ \\
\hline $\begin{array}{l}\text { Recommended mixing } \\
\text { ratio }\end{array}$ & $\mathrm{g}$ & 125 & 140 \\
\hline Cream time & $\sec$ & \multicolumn{2}{|c|}{$40.0 \pm 3.0$} \\
\hline Gel time & $\sec$ & \multicolumn{2}{|c|}{$250.0 \pm 10.0$} \\
\hline
\end{tabular}




$\begin{array}{lcc}\text { Free rise density } & \mathrm{Kg} / \mathrm{m}^{3} & 45.0 \pm 3.0 \\ \text { Demold time } & \min & >30\end{array}$

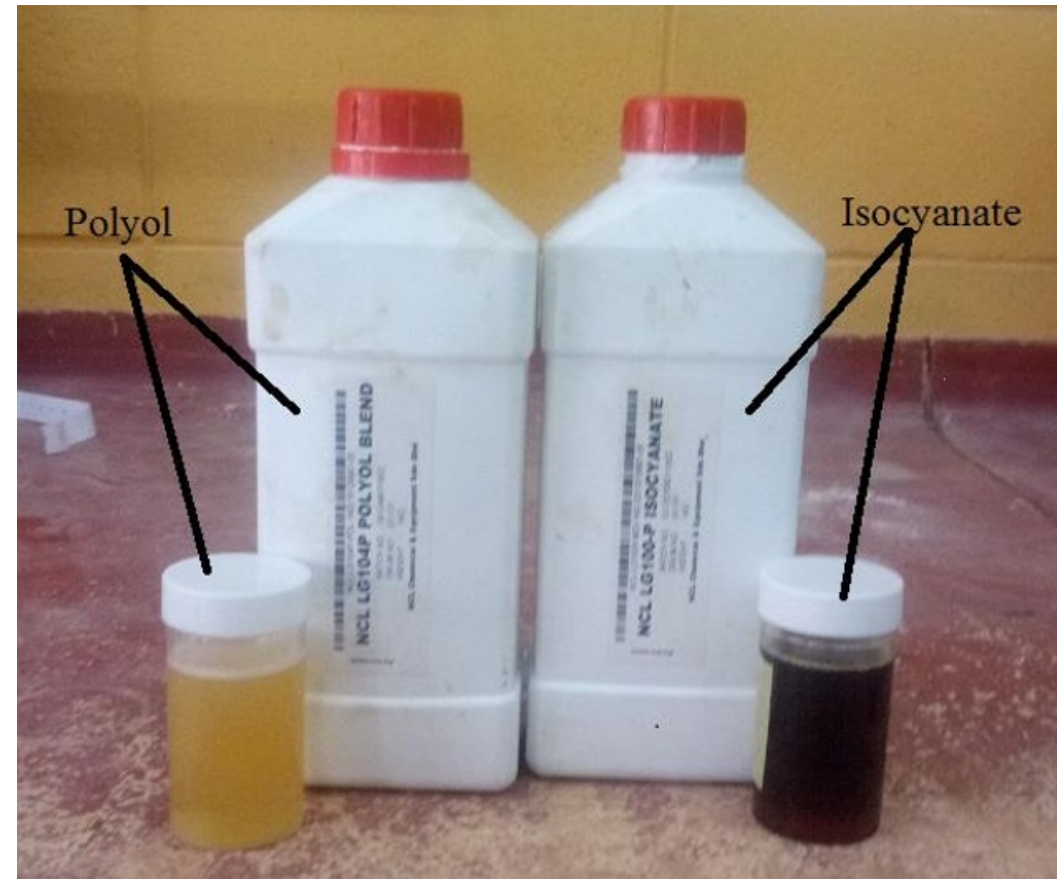

Fig. 1. Polyurethane consisting of Polyol and Isocyanate

\section{Results and discussions}

\subsection{Basic Material Properties}

The untreated marine clay was characterised based on the result of tests conducted in the laboratory. Table 2 shows the results of a characteristic of the marine clay. From this result, the marine clay under review has natural moisture content of $67 \%$, liquid limit and plastic limit of $65 \%$ and $26 \%$ respectively. These values are similar to the properties of marine clay reported by [1], [9], [44] and slightly lower than that reported by [18]. The result of the particles sizes distribution further confirmed that the soil has a fine fraction (particles smaller than 63um) up to $98 \%$, optimum moisture content (OMC) of $25 \%$ maximum dry density MDD of $1440 \mathrm{Kg} / \mathrm{m}^{3}$ and loss of ignition (LOI) of $8 \%$. All these values fall within the ranges of most common marine clay soils reported by many scholars as reviewed by [2]. However, the PH value of 3.25 for this marine clay has the acidic property that is unusual as reported by [45].

Table 2. Properties of marine clay

\begin{tabular}{ll}
\hline Properties & Results \\
\hline Natural moisture content & $67 \%$ \\
Liquid limit & $65 \%$ \\
Plastic limit & $26 \%$ \\
Gravel fraction & $0 \%$ \\
Sand fraction & $1.32 \%$ \\
Fines fraction & $98.68 \%$ \\
OMC & $25 \%$ \\
MDD & $1440 \mathrm{~kg} / \mathrm{m}^{3}$
\end{tabular}




$\begin{array}{ll}\text { PH } & 3.25 \\ \text { LOI } & 8 \%\end{array}$

\subsection{Effect of Polyurethane on the properties of marine clay}

Table 3Error! Reference source not found. and Fig. 2. UCS test result of marine clay at varying dose of Polyurethane. The result shows the effect of Polyurethane on the shear strength parameters of marine clay. The result revealed that $5 \%$ of Polyurethane improved the shear strength of the marine clay from $75 \mathrm{kpa}$ to $250 \mathrm{kpa}$ (more than 230\%) improvement. This improvement of the shear strength of marine also caused the corresponding decrease in the cumulative strain of the marine clay from $5.18 \%$ to $2.92 \%$ (that correspond to more than $77 \%$ decrease) in the cumulative strain of the marine clay. This result shows that the marine clay which is not suitable in its natural condition for use as subgrade material or as foundation materials can be improved by application polyurethane as a stabiliser.

Table 3. Result of the effect of Polyurethane on marine clay

\begin{tabular}{cccc}
\hline \multicolumn{4}{c}{ All Stages Conditions at Failure } \\
\hline $\begin{array}{c}\text { Polyurethane } \\
\text { content }(\%)\end{array}$ & $\begin{array}{c}\text { Maximum Corrected } \\
\text { Deviator Stress (kPa) }\end{array}$ & $\begin{array}{c}\text { Cumulative Strain } \\
(\%)\end{array}$ & $\begin{array}{c}\text { Shear Strength } \\
(\mathbf{k P a}) \\
0\end{array}$ \\
150 & 5.18 & 75 \\
\hline 1 & 224 & 4.09 & 112 \\
2 & 110 & 0.60 & 55 \\
3 & 187 & 1.33 & 94 \\
4 & 412 & 1.86 & 206 \\
5 & 501 & 2.92 & 250
\end{tabular}

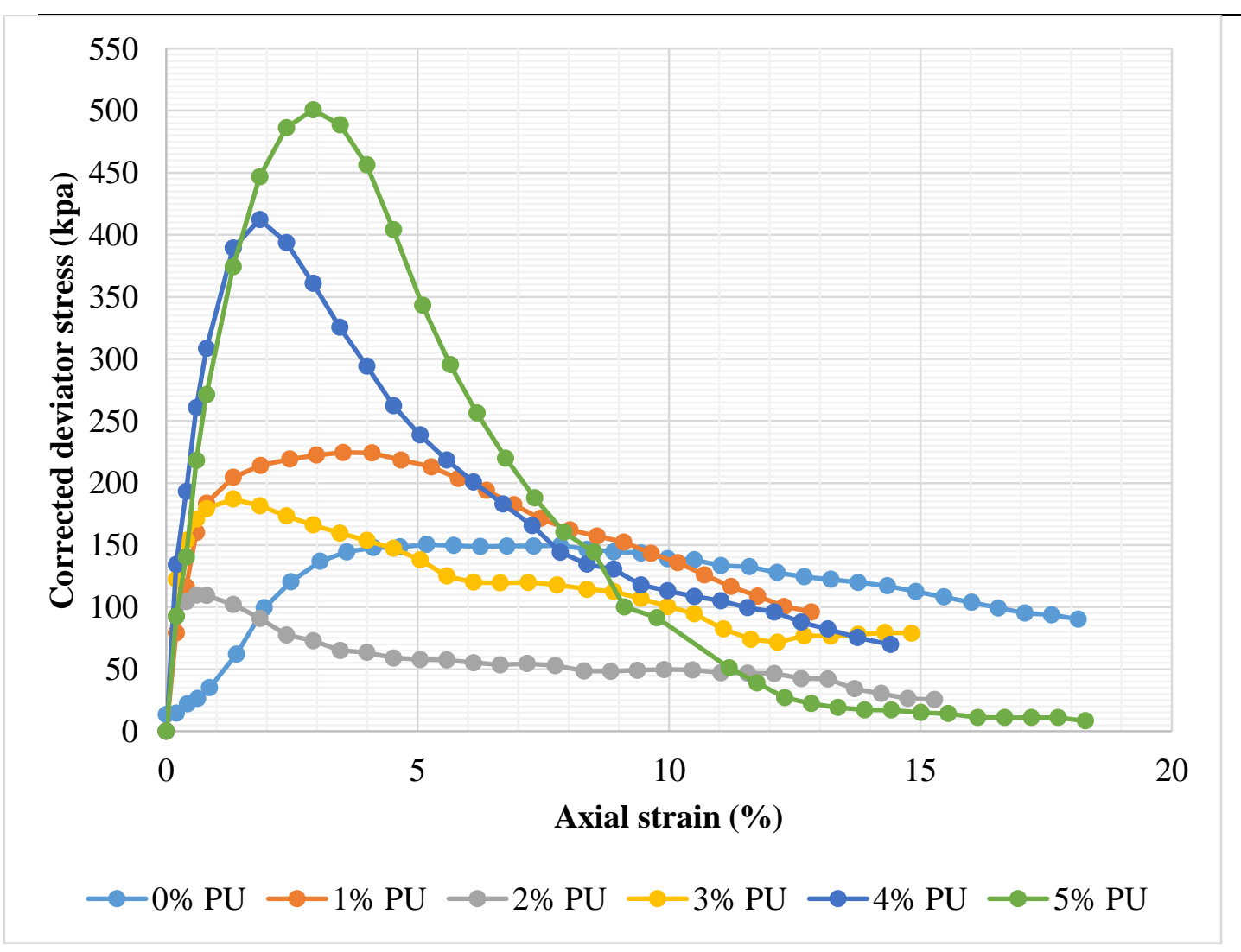


Fig. 2. UCS test result of marine clay at varying dose of Polyurethane

From the result of Table 3. Result of the effect of Polyurethane on marine clay, initially at $0 \%$ Polyurethane(untreated soil), the deviator stress was 150kpa. Adding 1\% Polyurethane into the soil causes the deviator stress to increases slightly, and a further increase in Polyurethane by $2 \%$ caused the deviator stress to drop below the initial value of deviator stress of untreated soil. However, subsequent increases of Polyurethane $(3 \%, 4 \%$ and $5 \%)$ caused continues to increase in deviator stress of the marine clay. The fluctuation in improvement between $1 \%, 2 \%$ and $3 \%$ Polyurethane content is probably from the sample preparation. Likely the $2 \%$ and $3 \%$ specimen were extruded before the Polyurethane finish reaction and hardened in the mould. Moreover, that caused the specimen to be cracked, and it cannot attain the exact strength.

Furthermore, attempt to increases the Polyurethane content above $5 \%$ proved abortive, as the mould can no longer accommodate the volume of the soil mixed with the Polyurethane. At the polyurethane content more than $5 \%$, once the reaction of Polyurethane commences, the mixture of Polyurethane foam and soil will force its way out of the mould due to the numerous increase in the volume of Polyurethane during the reaction [46]. The Polyurethane increases in volume up to 20 times of its original volume [47]. That increase in volume can cause uplifting of a depressed section of concrete pavement to the desired level [31]. The expansion of the Polyurethane also results in demanding only a small quantity of Polyurethane, that results in the cost saving.

\section{Conclusion and recommendations}

From the information gathered and the experimental studies conducted, the following conclusions and recommendations are made on the application of Polyurethane for stabilisation of marine clay.

\subsection{Conclusion}

The results of the preliminary results showed that the soil has all the attributes of marine clay such as a liquid limit of $65 \%$, plastic limit of $26 \%$ and plasticity index of $53 \%$, percentages of gravel, sand and fines in the sample respectively equal to $0 \%, 1.32 \%$ and $98.68 \%$. Compaction characteristics of the soil (OMC and MDD equal to $25 \%$ and $1440 \mathrm{~kg} / \mathrm{m}^{3}$ ) respectively. A soil $\mathrm{PH}$ of 3.25 and LOI equal to $8 \%$. All these confirmed that the soil is marine clay and is not suitable for construction purposes at its natural condition.

Stabilizing the marine with the polyurethane improved the shear strength of the marine clay from $75 \mathrm{kpa}$ to $250 \mathrm{kpa}$ it further reduces the cumulative strain of the soil from $5.18 \%$ to $2.92 \%$ which correspond to improvement by $230 \%$ increase in shear strength and $77 \%$ decrease in cumulative strain.

Utilization of Polyurethanes a stabilisation material for marine clay is technically viable mainly due to its short gelling and hardening time will make it an excellent and quick improvement method, speedy construction and handy for remedial works. The multiples increase in the volume of Polyurethane also confirmed during sample preparation Polyurethane and marine; and it will be the useful maintenance of depressed pavement, road hydraulic structures, buildings and other underground construction where standard or conventional method will be infeasible.

\subsection{Recommendations}

A further study is recommended on the sample preparation to determine the time limit of completing the mixing and compacting the marine clay and Polyurethane foam into the mould, and the minimum time the sample must stay in the mould before it can be extruded out.

The authors are thankful for support by the fundamental research grant (FRGS) vote no R.J130000.7822.4F885, Universiti Teknologi Malaysia, Johor Bahru, Malaysia. The first author also grateful to the support provided by the Tertiary Education Trust Fund (TETFund) of the Federal Republic of Nigeria.

\section{References}

1. J. Wang, L. Guo, Y. Cai, C. Xu, and C. Gu, "Strain and pore pressure development on soft marine clay in triaxial tests with a large number of cycles," Ocean Eng., vol. 74, pp. 125-132, Dec. (2013).

2. M. A. M. Al-Bared and A. Marto, "A Review on the Geotechnical and Engineering Characteristics of Marine Clay and the Modern Methods of Improvements," Malaysian J. Fundam. Appl. Sci., vol. 13, no. 4, pp. 825-831, (2017).

3. A. P. Panda and S. Narasimha Rao, "Undrained strength characteristics of an artificially cemented marine clay,” Mar. Georesources Geotechnol., vol. 16, no. 4, pp. 335-353, (1998). 
4. G. Kang, T. Tsuchida, and A. M. R. G. Athapaththu, "Engineering behavior of cement-treated marine dredged clay during early and later stages of curing," Eng. Geol., vol. 209, pp. 163-174, Jul. (2016).

5. H. W. Xiao, F. H. Lee, and K. G. Chin, "Yielding of cement-treated marine clay," Soils Found., vol. 54, no. 3, pp. 488-501, (2014).

6. G. o. Kang, T. Tsuchida, and Y. sang Kim, "Strength and stiffness of cement-treated marine dredged clay at various curing stages," Constr. Build. Mater., vol. 132, pp. 71-84, (2017).

7. H. W. Xiao and F. H. Lee, "Curing Time Effect on Behavior of Cement Treated Marine Clay," vol. 2, no. 7, pp. 144-151, (2008).

8. S. Sasanian and T. A. Newson, "Basic parameters governing the behaviour of cement-treated clays," Soils Found., vol. 54, no. 2, pp. 209-224, (2014).

9. N. Z. Mohd. Yunus et al., "Performance of lime-treated marine clay on strength and compressibility chracteristics," Int. J. GEOMATE, vol. 8, no. 2, pp. 1232-1238, (2015).

10. D. Rao, P. Pranav, and V. Ganja, "A Laboratory Study on the Lime and Sawdust Treated Marine Clay Sub Grade Flexible Pavement under Cyclic Pressure,” Int. J. Eng. Innov. Technol., vol. 2, no. 4, pp. 207-210, (2012).

11. D. K. Rao, V. Ganja, P. R. T. Pranav, and R. H. Ash, “A Laboratory Study of Cyclic Plate Load Test on Lime and Rice Husk Ash Treated Marine Clay Subgrade Flexible Pavements,” vol. 2, pp. 4465-4469, (2012).

12. G. Rajasekaran and S. N. Rao, "Effect of Pollutants on the Physical and Engineering Behavior of LimeTreated Marine Clay," Mar. Georesources Geotechnol., vol. 19, no. 1, pp. 17-35, Jan. (2001).

13. C. Phetchuay, S. Horpibulsuk, A. Arulrajah, C. Suksiripattanapong, and A. Udomchai, "Strength development in soft marine clay stabilized by fly ash and calcium carbide residue based geopolymer," Appl. Clay Sci., vol. 127, no. 128, pp. 134-142, (2016).

14. S. Saleh, "Micro Level Analysis of Weak Soils Stabilized with Locust Bean Waste Ash ( LBWA )," Int. J. Civ. Eng. Constr. Sci., vol. 2, no. 2, pp. 9-15, (2015).

15. S. Saleh and S. Srividhya, "Stabilization of Weak Soils using Locust Bean," Int. J. Res. Eng. Sci. Technol., vol. 1, no. 3, pp. 1-6, (2015).

16. J. E. Sani, A. O. Eberemu, T. S. Ijimdiya, and K. J. Osinubi, "Effect of Locust Bean Waste Ash on the Strength Properties of Black Cotton Soil Using Cement Kiln Dust as an Activator," in Department of Civil Engineering, Ahmadu Bello University, Zaria, no. 1, pp. 249-257, (2014).

17. S. Saleh, "Improving the Strength of Subgrade Soils using Locust Bean Waste Ash (LBWA)," J. Civ. Eng. Environ. Technol., vol. 3, no. 2, pp. 180-184, (2016).

18. S. Teresa and J. Annie, "Study on the Effects of Marine Clay Stabilized with Banana Fibre," Int. J. Sci. Eng. Res., vol. 4, no. 3, pp. 2347-3878, (2014).

19. P. T. Ravichandran, A. S. Prasad, K. D. Krishnan, and P. R. K. Rajkumar, "Effect of Addition of Waste Tyre Crumb Rubber on Weak Soil Stabilisation," Indian J. Sci. Technol., vol. 9, no. 5, (2016).

20. A. Upadhyay and S. Kaur, "Review on Soil Stabilization Using Ceramic Waste," Int. Res. J. Eng. Technol., vol. 03, no. 07, pp. 1748-1750, (2016).

21. Y. Yi, L. Gu, and S. Liu, "Microstructural and Mechanical Properties of Marine Soft Clay Stabilized by Lime-Activated Ground Granulated Blast Furnace Slag," Appl. Clay Sci., vol. 103, pp. 71-76, Jan. (2015).

22. P. Faizal, M. Aminaton, M. Y. N. Zurairahetty, A. T. S. Azhar, and T. C. Soon, "Effect of Sodium Silicate as Liquid Based Stabilizer on Shear Strength of Marine Clay," J. Teknol., vol. 76, no. 2, pp. 45-50, (2015).

23. Z. Yang, X. Zhang, X. Liu, X. Guan, C. Zhang, and Y. Niu, "Flexible and stretchable polyurethane/waterglass grouting material," Constr. Build. Mater., vol. 138, pp. 240-246, May (2017).

24. D. F. Grouting, "Grouting Materials," in Dam Foundation Grouting, Reston, VA: American Society of Civil Engineers, pp. 87-136, (2007).

25. E. A. Vik et al., "Experiences from environmental risk management of chemical grouting agents used during construction of the Romeriksporten Tunnel," Tunn. Undergr. Sp. Technol., vol. 15, no. 4, pp. 369378, (2000).

26. S. Kazemian, B. B. K. Huat, A. Prasad, and M. Barghchi, “A review of stabilization of soft soils by injection of chemical grouting,” J. Appl. Sci. Res., vol. 6, no. 12, pp. 5862-5868, (2010).

27. B. Chun, D. S. Ryu, C. Shin, G. Im, J. Choi, and H. Lim, "The Performance of Polyurethane Injection Method with Soil Nailing System for Ground Reinforcement," in Ground improvement geosystems ICE Publishing, pp. 445-451, (1997).

28. R. Valentino and D. Stevanoni, "Behaviour of reinforced polyurethane resin micropiles," in Institution of Civil Engineers, Geotechnical Engineering 169, vol. 169, no. GE2, pp. 187-200, (2016).

29. M. Bayati and J. Khademi Hamidi, "A case study on TBM tunnelling in fault zones and lessons learned from ground improvement," Tunn. Undergr. Sp. Technol., vol. 63, pp. 162-170, (2017).

30. L. Priddy, S. Jersey, and C. Reese, "Full-Scale Field Testing for Injected Foam Stabilization of Portland Cement Concrete Repairs," Transp. Res. Rec. J. Transp. Res. Board, vol. 2155, no. 1, pp. 24-33, Dec. 
(2010).

31. I. B. Mohamed Jais, "Rapid remediation using polyurethane foam / resin grout in Malaysia," Geotech. Reseach, vol. 4, no. GR2, pp. 107-117, (2017).

32. P. K. R. Vennapusa, Y. Zhang, and D. J. White, "Comparison of Pavement Slab Stabilization Using Cementitious Grout and Injected Polyurethane Foam," J. Perform. Constr. Facil., vol. 04016056, pp. 114, (2016).

33. S. Li, R. Liu, Q. Zhang, and X. Zhang, "Protection against water or mud inrush in tunnels by grouting: A review," J. Rock Mech. Geotech. Eng., vol. 8, no. 5, pp. 753-766, (2016).

34. D. K. Chattopadhyay and D. C. Webster, "Thermal stability and flame retardancy of polyurethanes," Prog. Polym. Sci., vol. 34, no. 10, pp. 1068-1133, (2009).

35. D. K. Chattopadhyay and K. V. S. N. Raju, "Structural Engineering of Polyurethane Coatings for HighPerformance Applications," Prog. Polym. Sci., vol. 32, no. 3, pp. 352-418, (2007).

36. S. A. Madbouly and J. U. Otaigbe, "Recent advances in synthesis, characterization and rheological properties of polyurethanes and POSS/polyurethane nanocomposites dispersions and films," Prog. Polym. Sci., vol. 34, no. 12, pp. 1283-1332, (2009).

37. S. Ramesh and K. Punithamurthy, "The effect of organoclay on thermal and mechanical behaviours of thermoplastic polyurethane nanocomposites," Dig. J. Nanomater. Biostructures, vol. 12, no. 2, pp. 331$338,(2017)$.

38. J. O. Akindoyo, M. D. H. Beg, S. Ghazali, M. R. Islam, N. Jeyaratnam, and A. R. Yuvaraj, "Polyurethane types, synthesis and applications - a review," RSC Adv., vol. 6, no. 115, pp. 114453-114482, (2016).

39. H. Janik and M. Marzec, "A review: Fabrication of porous polyurethane scaffolds," Mater. Sci. Eng. C, vol. 48, pp. 586-591, (2015).

40. BS 1377-1, "General requirements and sample preparation," (1990).

41. BS 1377-2, "Classification tests," 1990.

42. BS 1377-3, "Chemical and electro-chemical tests," (1990).

43. BS 1377-7, "Shear strength tests (total stress)," (1990).

44. A. Marto, M. R. Jahidin, N. A. Aziz, F. Kasim, and N. Z. Mohd. Yunus, "Stabilization Of Marine Clay Using Biomass Silica-Rubber Chips Mixture," IOP Conf. Ser. Mater. Sci. Eng., vol. 160, no. 1, p. 012084, Nov. (2016).

45. S. Basack and R. D. Purkayastha, "Engineering properties of marine clays from the eastern coast of India," vol. 1, no. 6, pp. 109-114, (2009).

46. C. Vipulanandan, M. B. Kazez, and S. Henning, "Pressure-Temperature-Volume Change Relationship for a Hydrophilic Polyurethane Grout," in Grouting and Deep Mixing, pp. 1808-1818, (2012).

47. B. N. Babcock, "Cement Grout vs . Chemical Grout: Which One to Use, When, and Why," A White Paper providing guidance to the Geotechnical Community, pp. 1-4, (2018). 